\title{
MUSLIM HUB: SPIRITUALITAS BISNIS MUSLIM DI ERA INDUSTRI 4.0
}

\author{
MUHAMMAD BAEHAQI \\ Sekolah Tinggi Ilmu Ekonomi (STIE) Putra Bangsa \\ baehaqimuhammad@gmail.com
}

\begin{abstract}
ABSTRAK
Tulisan ini bertujuan untuk mendiskusikan spiritualitas bisnis dalam komunitas muslim yang memberi andil cukup besar dalam membangun eksistensi etitas bisnis muslim di pasar global. Komunitas muslim adalah kekuatan bisnis yang diperhitungkan karena keluasan dari sisi jumlah, juga peningkatannya dari sisi growth. Pendekatan yang dipakai adalah pendekatan kualitatif dengan mengungkap data-data sekunder yang sudah dirilis sebelumnya oleh penulis yang lain dan isajikan dalam bentuk artikel naratif. Tulisan ini memberikan kontribusi untuk pengakuan "muslim hub" sebagai pengembangan wawasan baru ke dalam literasi bisnis muslim dalam kaitannya menciptakan mekanisme kolaboratif diantara entitas-entitas bisnis yang terlibat. Sebuah peta konsep untuk menawarkan gambaran yang lebih spesifik tentang karakteristik, motivasi, dan potensi pasar bisnis komunitas muslim.
\end{abstract}

Kata kunci: muslim hub, industry 4.0, komunitas muslim.

\section{PENDAHULUAN}

Tahun 1989 adalah tahun yang sangat signifikan bagi momentum terbentuknya tata dunia baru. Perang dingin antara dunia Barat (dominasi pemikiran kapitalis) dan dunia Timur (representasi pemikiran sosialis) seolah berakhir dengan runtuhnya tembok Berlin sebagai simbol pembatas ideologi Barat dan Timur. Hasilnya adalah munculnya dominasi ekonomi kapitalis yang dimotori oleh kekuatan ekonomi Amerika sebagai representasi Barat. Efek dari hegemonitas tersebut, dunia membutuhkan hamparan luas untuk menampung dan menghabiskan produk-produk teknologi yang digerakkan oleh kekuatan revolusi industri. Akibatnya, kekuatan revolusi industri menggeser fokus perhatian dari negara-negara industri berkekuatan produksi, menuju negaranegara berkekuatan pasar. Globalisasi adalah senjata ampuh untuk mendobrak terbukanya "pasar dunia" untuk memuluskan kekuatan kapitalisasi industri menuju negara-negara berkekuatan pasar (Neisbitt, 1995).
Dampak dari revolusi industri tidak saja berkaitan dengan kekuatan produksi dan pasar, namun merambah ke semua aspek kehidupan. Beberapa yang sangat menonjol adalah pegeseran peran negara dan swasta dalam penciptaan kesejahteraan, gaya hidup global dan munculnya nasionalisme kultural, munculnya kejayaan individu sebagai konsekuensi penguasaan bisnis dan aset perekonomian, serta pergeseran spiritualitas masyarakat modern yang mendewakan seni dan teknologi. Sebuah lompatan perubahan yang jauh-jauh hari sudah diramalkan oleh John Neisbitt (1991), melalui megatrend 2000. Sisi buruknya, benturan perubahan menjadi bagian permasalahan dari revolusi industri, karena harus berhadapan dengan benturan budaya-budaya lokal. Akibatnya, dunia seolah-olah semakin mencekam. Dunia menjadi arena yang sempit dengan keterbatasan-keterbatasan sumber daya yang ada. "Perang" tak terhindarkan. Perebutan pengaruh melalui hegemoni ekonomi dan hegemoni politik menjadi sisi lain dari wajah revolusi industri yang 
disembunyikan. Sementara wajah indah yang tampak adalah kesetaraan di dalam human right, keindahan demokrasi, dan kesejahteraan dalam pasar global. Sebuah personifikasi yang mengagumkan tentang prinsip-prinsip hidup yang universal.

Dari sisi yang berbeda, komunitas muslim adalah komponen yang sangat menentukan. Muslim bukan saja merujuk pada penganut ajaran Islam semata, namun lebih jauh dari itu, muslim adalah penghuni hampir seperlima masyarakat dunia yang tersebar di lebih dari lima puluh negara. Sebuah kalkulasi yang sangat menjanjikan jika dilihat dari ukuran pasar. Menurut Pusat Riset Agama dan Kehidupan Sosial Pew (2011), saat penduduk dunia diproyeksikan tumbuh $35 \%$ dalam empat dekade kedepan, masyarakat muslim dunia diperkirakan tumbuh $73 \%$, dari 1,6 milyar di tahun 2010, akan menjadi 2,8 milyar di tahun 2050. Di tahun 2030, diperkirakan $26,5 \%$ penduduk dunia adalah penganut Islam, dengan kata lain satu diantara empat orang penduduk bumi adalah pemeluk Islam. Negara BRIC (Brazil, Rusia, India, dan Tiongkok) sebagai negara dengan poplasi terpadat di muka bumi, akan menjadi tuan rumah bagi 300 juta penduduk muslim. Disaat populasi Barat mulai menua, populasi muslim justru masih berusia muda dan produktif. Pada tahun 2010, 63\% atau hampir dua per tiga muslim dunia masih berusia di bawah 30 tahun, yang berarti pada tahun 2020 mendatang mereka tengah berada pada masa kedewasaannya di usia 40 tahun(Shelina, 2017).

Kalkulasi demografis sebagai aset produktif dan kekuatan pasar bukanlah satu-satunya alasan yang menjadikan kapitalisasi dunia Barat menjadi khawatir, di hadapan mereka, pertumbuhan ekonomi terus menurun, dan pengaruh ekonomi perlahan-lahan beralih ke dunia muslim dan Timur. Negara-negara seperti Indonesia,
Turki dan negara-negara Asia Timur lainnya adalah negara-negara yang senantiasa dihitung dalam proyeksi pertumbuhan ekonomi yang progresif. Sementara ketergantungan negara-negara Barat terhadap sumber minyak bumi dan gas dengan negara-negara Islam di Timur Tengah, adalah fakta lain betapa negaranegara Islam dengan populasi mayoritas muslim memegang pengaruh yang sangat kuat.

Indonesia adalah negara dengan populasi penduduk muslim terbesar di dunia. Bahkan jika dikalkulasi, populasi muslim di 16 negara di kawasan Timur Tengah hanya berkisar $97 \%$ dari populasi muslim di Indonesia, Afrika di 5 negara hanya berkisar $79 \%$ dari populasi muslim Indonesia. Dengan populasi sebesar itu, maka hampir dipastikan Asia khususnya Timur Tengah dan Indonesia akan menjadi pusat perhatian bagi perkembangan bisnis muslim di dunia. Di era industri 4.0 seperti sekarang ini, kalkulasi populatif menjadi faktor yang sangat signifikan. Karena di era ini, konfigurasi pasar tidak terfragmentasi secara vertikal, namun terfragmentasi secara horizontal. Ini berarti bahwa penduduk yang banyak adalah aset pasar yang potensial, dan aset pasar yang besar berarti peluang dan kekuatan bisnis yang sangat menjanjikan. Hal inilah yang menjadikan topik yang berkaitan dengan "muslim" dan "komunitas muslim" menjadi hangat dan krusial. Tujuan artikel ini adalah untuk mengkaji dan mendiskusikan mengapa dan bagaimana komunitas muslim menjadi salah satu faktor kunci dalam pemasaran global. Diawali dengan kajian potensi pasar yang ditimbulkan, pergeseran paradigmanya, serta sisi paradok yang ditimbulkan oleh konfigurasi pasar dan peran tren industry 4.0, sehingga menghasilkan terminologi "muslim hub" yang menjadi inti kajian. 
HUMAN SPIRIT CAPITAL

Mengapa muslim menjadi kekuatan pasar yang sangat diperhitungkan? Karena munculnya kelas menengah muslim yang kian hari kian tumbuh. Konfigurasi demografis penduduk muslim dunia yang berada diambang masa-masa produktif, dan tumbuhnya ekonomi di negara-negara yang mayoritas penduduknya muslim menjadi pemicu tumbuhnya kelas menengah muslim yang sangat pesat. Kelompok ini dicirikan dengan komunitas muslim yang memiliki basis religious yang kuat, modern, dan memiliki kemampuan ekonomi yang kuat. Ditambah dengan populasi muslim yag tumbuh melebihi rata-rata pertumbuhan penduduk dunia, dalam tiga dekade kedepan, muslim diperkirakan menjadi kekuatan ekonomi yang sangat diperhitungkan (Yuswohady (2014).

Derivasi nilai-nilai religiusitas Islam termanifestasi melalui branding dan platform Islam dalam dunia bisnis muslim. "Bisnis halal" sebagai platfom syar'i misalnya, telah merebak menjadi komoditas di banyak sektor. Tidak hanya makanan dan minuman, bisnis halal telah masuk pada lingkup bisnis gaya hidup seperti kosmetik, hijab, pakaian muslim, pariwisata, perhotelan bahkan sistem perekonomian dan perbankan syariah. Industri makanan dan gaya hidup halal diperkirakan memberi kontribusi terhadap perekonomian mencapai $\$ 1,8$ triliun pada thun 2014, dan diprediksi akan terus meningkat hingga $\$ 2,6$ triliun pada tahun 2020, dan secara berurutan keuangan Islam meningkat hingga $\$ 1,3$ triliun dan $\$ 2,6$ trilyun. Dan kelas menengah muslim diperkirakan akan tumbuh tiga kali lipat dari perkiraan 300 juta pada tahun 2015 menjadi 900 juta pada tahun 2030 (Shelina, 2017). Meski angka-angka tersebut merupakan angka perkiraan kasar, namun cukup memberi gambaran betapa bisnis halal dan tumbuhnya kelas menengah muslim menjadi sesuatu yang fenomenal. Yuswohady

menggambarkan posisi kelas menengah muslim sebagai stratifikasi sosial yang sangat penting dan fundamental. Berbeda dengan teori kelas yang diusung oleh Karl Marx yang mengedepankan dialektika materialisme, kelas menengah muslim lebih merunjuk kepada keseimbangan duniawi dan ukhrawi. Kelas menengah muslim dicirikan sebagai "identitas" yang dibangun diatas empat pilar fundamental.

\begin{tabular}{|c|c|c|c|}
\hline Religious & Modern & $\begin{array}{l}\text { Universal } \\
\text { Goodness }\end{array}$ & High Buying Power \\
\hline $\begin{array}{l}\text { - Iman } \\
\text { - Islam } \\
\text { - Ikhsan }\end{array}$ & $\begin{array}{l}\text { - Knowledgeable } \\
\text { - Tech Savvy } \\
\text { - Global }\end{array}$ & $\begin{array}{l}\text { - Rahmatan lil } \\
\text { 'alamin } \\
\text { - Humanity } \\
\text { - Inclusive }\end{array}$ & $\begin{array}{l}\text { - High } \\
\text { Consumption } \\
\text { - High Investment } \\
\text { - High Giving }\end{array}$ \\
\hline
\end{tabular}

Sumber: Yuswohady, 2017.

Islam sebagai agama wahyu, mengajarkan kepada semua pemeluknya tentang sistem ke-Tuhanan (iman) yang harus diyakini dalam setiap keadaan. Islam memberi tuntunan interaksi kemanusiaan yang bersifat vertikal (hablumminallah) dan yang bersifat horisontal (hablumminannas). Karenanya Islam menjadi "sumber nilai" bagi lahirnya tata nilai (norms) dalam kehidupan manusia baik secara lokal maupun global.Tuntunan itulah yang membawa kehidupan muslim pada nilai-nilai kebaikan (ikhsan) yang mengedepankan keseimbangan dunia dan akhirat dalam tata kelola kehidupannya.

Kehidupan modern adalah ciri yang melekat pada kelompok menengah muslim. Pemikiran yang terbuka, melek teknologi, inovatif dan menyukai tantangan adalah bagian dari kehidupan mereka. Dengan bekal pengetahuan dan pendidikan yang cukup, kelompok ini memiliki rasionalitas dalam berfikir dan mengambil keputusan, sehingga memiliki filter system dalam 
dirinya untuk mencerna persoalan dan tantangan masa depan. Mereka menempatkan dirinya sebagai bagian kontestasi dunia yang serba dinamis, sehingga adopsi nilai-nilai universal seperti humanitas, kesetaraan, dan sikap inklusif, menjadi solidaritas yang tak terpisahkan dalam kesehariannya.

Industri 4.0 telah memicu revolusi pengetahuan dan menciptakan apa yang disebut knowledge economy. Bagi kalangan kelas menengah, masalah fisiologis untuk bertahan hidup dianggap sesuatu yang sudah terpenuhi. Karena itu nilai-nilai capaian bergeser kearah kesejahteraan subyektif (subjective well-being), aktualisasi diri (self actualization), dan kualitas hidup (quality of life). Mereka mulai menekankan pentingnya perlindungan terhadap lingkungan, persamaan gender, partisipasi terhadap keputusan-keputusan ekonomi politik, kebebasan individu, dan demokrasi.Keyakinan yang teguh mereka kepada Islam sebagai agama yang sejuk, damai, dan penuh kasih sayang. Oleh karena itu mereka tertuntut untuk saling mengenal, saling berbuat baik, saling berbuat adil dan saling membantu sesama meskipun berbeda keyakinan, berbeda ras, suku ataupun golongan. Sifat inklusifme menjadi daya dorong kelas menengah muslim sebagai konsekuensi atas keluasan literasi peradaban, obyektifitas perspektif humanisme, yang kesemuanya bersandar pada nilai-nilai ajaran Islam.

Kekuatan vital dari kelas menengah adalah kemampuan secara ekonomi yang sudah mumpuni. Kemampuan ini yang menjadikan mereka memiliki akses terhadap sumber daya, literasi, dan kemapanan dalam pengambilan keputusankeputusan ekonomi. Discretionary income yang mereka miliki memungkinkan kelas menengah untuk menjadi konsumen yang potensial, namun disisi lain mereka juga sanggup menjadi kreator dan inisiator bisnis yang handal. Kemampuan inilah yang kemudian memicu kelas menengah muslim bergulir laksana bola salju yang terus membesar dari sisi potensi dan populasi. Sebuah kekuatan yang sangat diperhitungkan oleh kelompok manapun. Kekuatan transformasi kelas menengah yang sanggup memotivasi kelas di bawahnya, dan sanggup mendobrak bagi kelas diatasnya.

Dengan kemampuan empat karakter tersebut, kelas menengah muslim menjadi potensi yang sangat besar bagi perkembangan bisnis global. Perkembangan perilaku psiko-ekonomis kelas menengah muslim secara taktis dapat dikembangkan di dalam matrik prilaku berikut. 


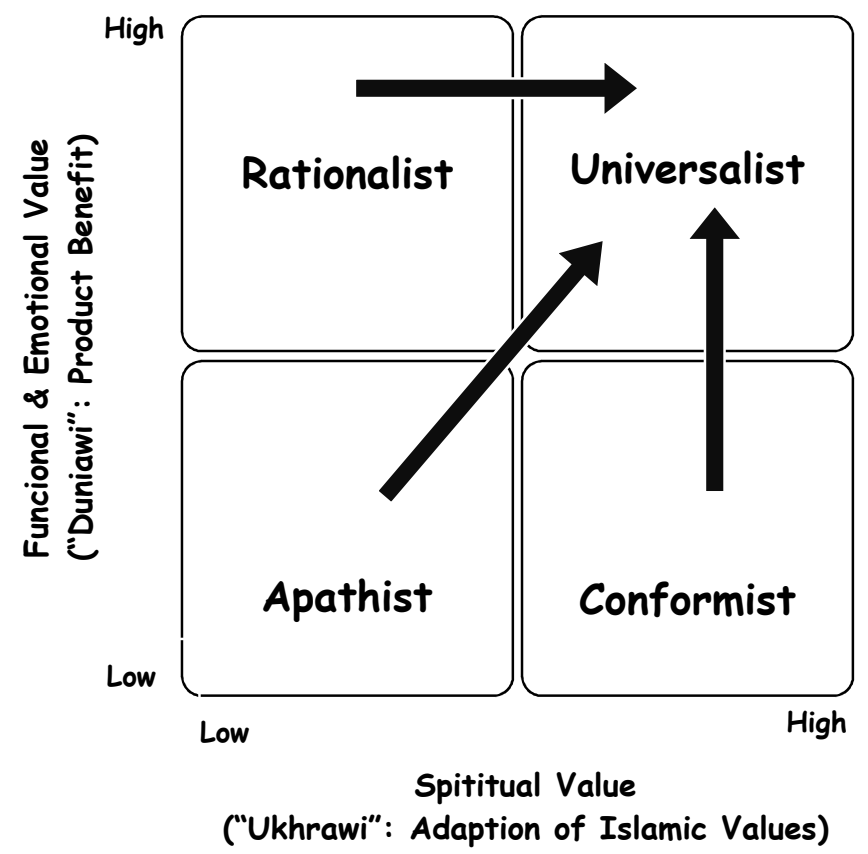

Gambar 1. Matrik Perilaku Stratejik

Sumber: Yuswohady, 2014.

Pertama, pergerakan horizontal kelas menengah muslim kearah kanan menunjukkan bahwa kehidupan mereka yang semakin religius. Mereka semakin menuntut spiritual value. Ini menunjukkan bahwa mereka memiliki mainstream yang tegas dalam pengambilan keputusankeputusan krusial dalam kehidupan mereka. Religiusitas menjadi mindset utama dalam pengambilan keputusan. (Halal dulu, baru yang lain...) adalah salah satu contoh prinsip yang dipegang teguh oleh mereka.

Kedua, pergerakan keatas secara vertikal, menunjukkan bahwa kelas menengah muslim memiliki keterbukaan intelektual sebagai buah dari tingkat pendidikan dan literasi yang dimiliki. Keputusan-keputusannya didasari oleh sikap rasional, sehingga tidak mudah dipengaruhi oleh dunia luar yang tidak sepaham dan seirama. Mereka semakin berpengetahuan, semakin modern, techy, makmur dan semakin berwawasan global.
Sehingga mereka cerdas dan demanding dalam melakukan konsumsi pembelian.

Sangat diyakini bahwa saat ini kehidupan kelas menengah muslim sudah berada pada posisi pergerakan ke kanan atas. Artinya semakin hari mereka semakin menjadi universalist. Mereka sangat religious, berkecukupan secara materiil, modern dan universal. Gerakannya tidak saja mewakili dirinya, tetapi mewakili masyarakat dunia yang universal. Hal ini berarti bahwa semakin besar keterwakilan kelas menengah muslim ke dalam matrik universal, maka semakin besar peranan yang dapat dipegang oleh masyarakat muslim dunia, karena disinilah human spirit capital yang sesungguhnya dimiliki oleh kelas menengah muslim. Ini tidak saja menunjukkan kekuatan pasar yang sangat besar dari sisi size, namun juga menunjukan kekuatan pasar dari sisi growth. Sesuatu yang sangat dikhawatirkan oleh dunia Barat dan non muslim, karena dapat mengancam 
hegemoni kekuatan ekonomi-politik mereka selama ini.

\section{MUSLIM COMMUNITIZATION}

Dalam kurun tiga dasa warsa terakhir, dunia bisnis mengalami perubahan yang sangat signifikan. Revolusi industry 4.0 mengantarkan peradaban pada fase cyber-physic berstruktur moduler (Wikipedia.org) yang memungkinkan setiap orang untuk terlibat dalam sebuah jejaring yang sangat kuat dalam waktu yang bersamaan. Secara spektakuler, revolusi ini telah menghasilkan pabrik cerdas yang mampu memberi salinan dunia fisik secara virtual, dan memberi mata rantai nilai dalam segala aspek kehidupan. Tata dunia baru yang digerakkan oleh komputasi awan memberi dominasi lahirnya budaya dan tata kelola bisnis yang sangat signifikan. "Dunia tanpa batas" menjadi kenyataan hidup bagi berkembangnya ide, gagasan, serta produk-produk cerdas yang mengagumkan. Wajah dunia telah dirubah melalui cara-cara digital.

Revolusi industry 4.0 adalah revolusi sistem komunikasi dan informasi yang terbangun secara horizontal. Di era ini, komunikasi dan informasi berkembang dengan sangat cepat, karenanya era ini disebut juga sebagai era revolusi digital. Teknologi digital menggantikan peranan komunikasi yang dilakukan human-tohuman. Karena sifatnya yang horizontal, maka komunikasi dapat terwakili melalui system human-to-machine, bahkan machine-to machine. Ruang dan waktu bukan lagi penghalang bagi manusia untuk berinteraksi, bahkan interaksi antar manusia bukan ditentukan atas dasar kedekatan antar aktor atau saling mengenal, namun mereka dipertemukan karena adanya kesamaan di dalam tujuan, nilai dan kepentingan (Seth Godin, 2009). Paradigma pemasaran pun mulai bergeser, paradigma produk yang awalnya penekanan pada marketing mix mengarah pada pembentukan human spirit, strategi pemasaran berubah sebagai konsep pemasaran berbagi co-creation, dan manajemen merek mulai menempatkan brand sebagai pembentukan karakter (Baehaqi, 2017).

Internet menciptakan nilai baru dalam ruang masyarakat global yang saling terhubung. Sejak internet diperkenalkan, disrupsi dalam berbagai industry tidak terhindarkan. Digital disruption melahirkan value innovation yang manandai masuknya era ekonomi pengetahuan (knowledge economy) dimana pengetahuan, informasi, pembelajaran, kreativitas, dan inovasi menjadi penentu kesuksesan (Yuswohady, 2017). Paradigma perekonomian mengalami pergeseran dari dunia agraris (agricultural age) bergerak menuju industri (industrial age), kemudian bergeser lagi kearah informasi (information age) dan pada akhirnya sampai pada era conceptual age atau era kreator (Danel, 2005). Nilai inovasi muncul seiring elaborasi yang dilakukan oleh para entrepreneur, creator, innovator yang dengan jeli mensiasati disrupsi industry menjadi peluang bisnis yang menjanjikan.

Komunitas muslim adalah bagian penting dalam era ini. Kata "umat" stidaknya mewakili komunitas muslim sebagai "bangsa muslim global" yang mewakili individu dengan kelompok yang saling terhubung dalam belahan dunia manapun. Sepanjang sejarah, gagasan umat memiliki kedudukan yang sangat kuat, namun di era digital inilah impian akan umat muslim yang saling terhubung menjadi kenyataan. Di era ini komunitas muslim berkesempatan menuju masyarakat dengan "knowledge economy" yang tangguh, Islam sebagai rahmatan lil alamin serta karaker inklusif yang dimiliki komunitas muslim dunia telah merubah komunitas muslim menjadi pelaku pasar yang strategis. High buying power didorong oleh nilai-nilai religiusitas, modern dan universal goodness melahirkan komunitisasi muslim di berbagai area hubungan, Komunitisasi yang terbangun 
karena adanya kesamaan propose, value dan interest (PVI) tidak terbatas pada aktifitas bisnis, melainkan juga pada sisi idieologis, budaya pop, aktifitas religi, maupun komunitas-komunitas lain yang dianggap "cool" sebagai perilaku masyarakat kekinian (Yuswohadi, 2017).

Di Inggris, Sehelina (2017) menggambarkan bahwa enterpreunership di kalangan muslim terbentuk sebagai akibat kesulitan mereka dalam mendapatkan menu konsumsi (halal) sehingga memicu mereka untuk menciptakan sendiri produk-produk makanan halal, atau kesulitan dalam mencari pakaian syar'i sehingga mereka mendirikan rumah-rumah produksi hijab. Komunitisasi terbentuk karena mereka memiliki PVI yang sama. Di Indonesia gerakan "penggiat Al Qur'an” menciptakan komunitas ODOJ (one day one juz) sebagai komunitas religi, komunitas anti riba, pecinta shodaqoh, dan sebagainya. Semua menunjukkan adanya kesamaan PVI di masing-masing area. Mereka terhubung satu sama lain, namun tidak saling mengenali secara personal. Internet menghubungkan mereka sebagai masyarakat global yang salin terhubung.

Dalam studi yang berbeda, Desi Kurnia Sari, at.al (2015) menyajikan temuan bahwa umat (bangsa muslim global) memiliki kekuatan untuk melakukan perlawanan terhadap produkproduk asing yang tidak dikehendaki. Perlawanan dilakukan melalui gerakkan boikot yang dimotivasi oleh sikap etnosentrisme komunitas muslim terhadap produk lokal. Orang-orang Turki lebih memilih produk lokal untuk alasan memajukan produk lokal, juga kalangan muslim Malaysia yang memilih produk local dengan alasan yang sama. Dengan demikian, gagasan tentang umat memberi transformasi tentang PVI yang kemudian membentuk komunitisasi-komunitisasi di area yang berbeda-beda dengan tujuan yang berbeda pula.

Nilai-nilai religiusitas muslim juga memberi alasan yang kuat terhadap pemboikotan. Penegakan "halal" dalam varitas produk-produk konsumsi, memotivasi gerakan penolakan terhadap produk asing. Khalil Al Hyari, at.al (2011) memberi alasan bahwa penolakan disebabkan karena adanya komitmen terhadap religiusitas dan afiliasi religiusitas. Sedikit berbeda dengan Desi Kurnia Sari, et.al, (2015), namun menemukan titik kesamaan dimana komunitas muslim adalah sebuah realitas pasar yang potensial dalam masyarakat global yang mampu menjadi kekuatan penangkis ketika PVI nya terusik. Namun dalam siuasi normal, bangsa muslim global adalah sebuah pasar yang sangat menjanjikan.

Wilson dan Grant, (2013) menunjukkan bahwa agama memiliki pengaruh signifikan terhadap proses pengambilan keputusan dari para pengikutnya. Studi ini menyimpulkan misalnya bahwa agama masih dianggap penting bagi sebagian orang di era globalisasi seperti ini. Agama menjadi sumber spiritualitas masyarakat global yang menggerakkan nilai-nilai, membentuk norma, serta mendorong manusia melakukan apa yang dianggap susuai dengan spiritualitas yang diyakini. Dan secara teknis, PVI menjadi agenda yang transparan yang memberi tanda kebersamaan untuk melakukan kegiatankegiatan transaksional maupun hubungan, sehingga komunitisasi terbangun.

Secara sederhana dapat dikatakan, bahwa komunitisasi adalah konsekuensi logis dari perkembangan komunikasi digital. Sebelum era ini terbangun, komunitisasi praktis hanya dibentuk berdasar kelompok-kelompok lokal yang sempit, terhubung secara offline, dan tidak memiliki spectrum yang luas. Sehingga yang sangat signifikan dalam era 4.0 adalah lahirnya tata dunia baru dalam konteks komunikasi pemasaran, yaitu penciptaan nilai baru yang dibangun diatas tatanan virtual. Prahalad dan Ramaswamy (2004) memperkenalkan konsep co-creation yang dibentuk oleh blok bangunan dialog, akses, 
resiko dan kepercayaan. Sebuah mekanisme komunikasi yang muncul sebagai respon atas perkembangan tuntutan entitas bisnis yang terlibat dalam area virtual. Pemikiran Vargo \& Lusch tentang logika service-dominant juga mencerminkan pengalaman interaktif dari kreasi pelanggan dalam konteks menciptakan hubungan dengan pemangku kepentingan (Vargo \& Lusch, 2008). Peran tersebut ditunjukan pada proses kolaboratif dalam model virtual yang menghasilkan organisasi-organisasi jaringan kolaboratif (Collaborative Networks Organization). Melalui jaringan $\mathrm{CNO}$ inilah kekuatan komunitas muslim menjadi sangat diperhitungkan, karena karakteristik modern dan memiliki high buying power.

\section{MUSLIM HUB: SEBUAH MEKANISME JARINGAN}

Konsep "umat" mungkin yang paling mendekati untuk menunjuk pada sebuah konsepsi hubungan atau jaringan kolaboratif muslim secara global. Umat dalam Islam sebenarnya tidak hanya merujuk pada sebuah arti "komunitas". Umat merujuk tentang makna pada sebuah arti "kesatuan" atau unity yang saling terhubung. Terhubung antara individu yang satu dengan lainnya, atau antara komunitas yang satu dengan komunitas lainnya. Konsepsi umat dalam Al Qur'an adalah penegasan tentang moral obligation sebagai makhluk sosial yang memiliki tanggungjawab horisontal dan vertikal, sehingga Al Qur'an merujuk pada sebuah konsepsi ideal "umat terbaik" (khaerul ummah) yang dilahirkan di tengah-tengah kehidupan kemanusiaan, dan menugaskan manusia pada "amar ma'ruf nahi mungkar” (Qur'an, 03: 104, 110). Dan inilah landasan idiil mengapa sesama manusia bersaudara, mengapa sesama manusia harus bekerjasama, saling membantu dan saling mengingatkan. Sebuah konsepsi inklusifisme teologis yang universal, yang menjadi pedoman dan seruan kepada umat muslim dimanapun mereka tinggal. Dalam penafsiran yang lain, terminologi umat mewakili sebagai "bangsa muslim global", menempatkan setiap individu ke dalam komunitas muslim yang lebih luas, dan memiliki hubungan langsung satu dengan yang lainnya dalam belahan dunia manapun. Arti paling mendalam menjadi bagian dari umat secara teoritis digambarkan dalam sebuah hadis Nabi Muhammad dengan perumpamaan "umat itu bagaikan satu tubuh, jika salah satu bagiannya disakiti, maka seluruh tubuh akan merasakan kesakitan yang sama". Cita-cita besar umat adalah bergerak sebagai satu entitas menyeluruh yang berjuang untuk satu tujuan yang sama (Shelina, 2017). Dalam ragam aplikasi, seorang muslim akan menunjukan integritasnya sebagai umat yang taat dalam menjalankan seruan ajaran, sehingga secara spesifik sesama muslim mengikatkan diri sebagai "unity platform" di area kehidupan sosial.

Meskipun dalam tataran ideal konsepsi umat mampu menggambarkan bagaimana sesama muslim memiliki saling keterlibatan, namun di tataran praktis tidak serta merta dapat dijadikan sebagai rujukan. Secara teoritis, dalam kaitan manajemen pemasaran hubungan (CRM), gagasan "saling keterlibatan" diadopsi secara kuat sebagai konsep dasar customer engagement yang kemudian melahirkan gagasan $\mathrm{co}$ ceation (Vivek, 2012). Istilah "keterlibatan" atau "terlibat" itu sendiri telah dipakai sebagai konstruksi berfikir untuk menggambarkan adanya mekanisme hubungan yang terjadi sebagai pengembangan model interaksi "firm to firm, atau firm to consumer, bahkan consumer to consumer" yang banyak digunakan dalam studi tentang co-creation, pengembangan keputusan dan interaksi. Namun demikian, tidak ada konsensus yang pasti yang menjadi landasan rujukan tentang dimensi keterlibatan. Beberapa studi menunjuk pentingnya dimensi emosional, dimensi kognitif maupun dimensi perilaku (Hollebeek et Al., 2014). Patterson, Yu, De Ruyter (2006) menyatakan bahwa dimensi utama dari 
keterlibatan konsumen adalah penyerapan, dedikasi, semangat, dan interaksi. Pendapat ini mendekati dengan pandangan Vivek (2009) yang mengidentifikasi lima dimensi keterlibatan konsumen secara konseptual yaitu; kesadaran, antusiasme, interaksi, tindakan dan pengalaman. Beragamnya pendapat mengenai dimensi "keterlibatan" menunjukkan disamping tidak adanya konsensus yang pasti, juga menguatkan bahwa dimensi keterlibatan merupakan sebuah kenyataan empirik yang didukung oleh studi unidimensi ataupun multidimensional (Kuvykaite, Rita \& Tarute, Asta; 2015).

Studi Wilson et. Al. (2013) tentang pemasaran bulan sabit menunjukkan eksistensi ajaran Islam yang memiliki relevansi yang sangat kuat terhadap paradigma pemikiran pemasaran modern. Identifikasi fenomena yang muncul dari Islam memberikan kesuburan landasan mengenai konsep-konsep baru bagi pembangunan teori generatif. Argumennya diletakkan atas sudut pandang yang mendalam tentang Islam, yang memiliki eksistensi yang relevan dalam beberapa perspektif; Pertama argumentasi ekonomi, dimana pemasaran Islam menunjukkan potensi pasar melalui nilai finansial dan keberlanjutan masa depan melalui tingkat populasi. Kedua, perspektif berbasis konsumen; dimana perspektif ini mengartikulasikan bahwa di luar nilai dan ukuran pasar yang besar, ada internalisasi nilai ajaran Islam yang mengikat konsumen untuk mengembangkan sebuah perspektif nilai yang menempatkan "laba atau keuntungan" sebagai sebuah kriteria, namun pada saat tertentu laba/keuntungan bukan menjadi perspektif utama dalam penentuan keputusan-keputusan tindakan. Ketiga, kehenndak geopolitik; dimana perdagangan yang terkait dengan Islam dipengaruhi oleh geopolitik, yang secara timbal balik mempengaruhi faktor-faktor seperti hubungan internasional, stabilitas politik, dan ekuitas merek nasional.

Secara kolektif, ketiga poin ini telah mendorong diakuinya pemasaran Islam sebagai bidang penting yang mampu menjadikan sebagai laboratorium pemikiran, dan pada tingkat makro, memberi kontribusi pengetahuan yang relevan dengan pemasaran utama. Pemasaran Islam telah muncul sebagai sebuah paradigma, dimana prinsipprinsipnya menjangkau lebih dari seruan terhadap muslim, namun dapat diterima oleh lintas paham dan agama di luar Islam. Sebagai sebuah analogi, pemikiran tentang pemasaran Islam telah diakui sebagai arus perkembangan pemikiran di dalam ilmu pemasaran dan manajemen seperti halnya beberapa arus pemikiran yang telah bergerak sebelumnya seperti manajemen Cina, feminisme, perdagangan yang adil, budaya Jepang dan manajemen kualitas total; dan berbagai arus pemikiran lainnya (Barney dan Zhang, 2009). .

Diatas pengakuan dan perkembangan pemikiran pemasaran, studi tentang "keterlibatan muslim" akhirnya menjadi topik penting dan tidak lagi berkonotasi konservatif. Pengakuan ini sekaligus menepis anggapan kaum "Islam phobia" yang cenderung memposisikan muslim sebagai kelompok marginal. Ketika secara faktual Islam telah menunjukkan peran terbuka dan inklusif dengan pertumbuhan pasar yang sangat menjanjikan, maka sulit dibantah jika "keterlibatan" muslim menjadi alur dominan yang sangat signifikan dalam skema pemasaran global. Kenyataan ini telah disadari oleh para pemikir dan praktisi pemasaran, namun demikian teorisasi baku yang melahirkan teminologi yang tepat belum dapat diungkapkan. Menjembatani konsepsi umat ke dalam term yang lebih operasional, sejauh ini para peneliti lebih banyak mengungkap dalam tataran identifikasi normatif seperti kajian tentang religiusitas muslim (Al Hyari et. al., 2012) atau religiusitas, etnosentrisme, halal bisnis maupun animosity (Desi Kurnia Sari \& at.al., 2015; Muhammad Nasrullah, 2015). Studi yang lebih spesifik yang mengarah pada keterlibatan muslim dalam mekanisme jaringan kolaboratif belum 
ditemukan. Untuk alasan inilah terminologi "muslim hub" digunakan sebagai konstruk yang yang menjelaskan "keterlibatan"dalam area jaringan. Kendati studi Wilson mengenai pemasaran bulan sabit dapat menunjukkan keterlibatan muslim melalui simbol kultural yang mampu diserap oleh kalangan di luar muslim, namun studi tersebut tidak mengungkap bagaimana gerakan muslim secara komunal mampu digerakkan melalui semangat kolektivisme kultural atas landasan ke-umatan. Solidarisme yang melahirkan semangat persaudaraan, ataupun semangat perlawanan misalnya, tidak mampu diungkan dalam teori-teori pemasaran hubungan. Muslim hub menjembatani untuk menjelaskan bahwa sesungguhnya ada mekanisme yang unik dan tidak terungkap dalam potensi pasar muslim yan besar, yaitu "solidaritas dan keberpihakan".

Di atas populasi besar dan terus tumbuh, masyarakat muslim dunia adalah pasar yang empuk untuk produk-produk global. Platform Islam dalam komoditi bisnis, bukan lagi dimiliki oleh masyarakat muslim semata, namun sudah menjadi milik masyarakat dunia yang berkepentingan. Bisnis halal adalah platform Islam, tetapi halal sudah menjadi milik masyarakat global. Merek global seperti Nestle, McDonald, KFC dan lainnya, mereka memiliki platform halal untuk melayani populasi muslim dunia. Mereka ada di semua negara, bahkan di negara yang mayoritas muslim penduduknya seperti Indonesia dan berbagai Negara di Timur Tengah. Sebuah bukti bahwa masyarakat muslim dunia adalah masyarakat yang adaptif di dalam perilaku bisnis dan konsumsi.

Pada saat kartun nabi Muhammad diterbitkan dalam sebuah koran di Denmark tahun 2005, atau saat Donald Trump mengumumkan Jerusalem sebagai ibukota Yahudi di awal tahun 2018, saat itu pula gelombang boikot terhadap produk-produk Denmark dan gelombang protes terhadap Amerika dan Yahudi bermunculan.
Kerugian demi kerugian mungkin dialami oleh perusahaan-perusahaan asal negara tersebut. Atau dalam analogi yang lain misalnya, apakah "Wardah" yang mengusung platform Islam dalam produknya dapat menuai kesuksesan sebagai top brand kosmetik seandainya di pasarkan di luar Indonesia seperti di Tiongkok atau India? Ini juga sebuah bukti bahwa komunitas muslim adalah pasar yang memiliki keunikan, adaptif, dan sekaligus memiliki kemampuan "menolak" dalam area bisnis global. Sebuah paradok yang krusial dan harus dicermati. .

Muslim Hub dibangun diatas tataran ideologis yang melibatkan Islam sebagai sumber nilai. Namun muslim hub juga ditopang oleh customer binding yang konsepnya dapat dijelaskan melalui theory reason actions (TRA) Fisbein dan Azjen (Riptiono, 2017). Dalam kaitannya dengan relationship marketing, muslim hub juga menunjuk adanya customer engagement dan co-creation (Vivek, 2014) dalam sebuah mekanisme tawar menawar pasar. Muslim hub merangkum karakteristik spesifik di dalam sikap dan perilaku, pengambilan keputusan, manufacturing, distribusi, maupun dalam mekanisme finansial kelompok bisnis muslim, sehingga menghasilkan keunggulan relatif di dalam persaingan. Oleh karena itu muatan dalam muslim hub tidak sematamata muatan bisnis, namun juga dapat berisi muatan-muatan religius, social, politik dan lainnya. Dengan kata lain, muslim hub dalam tulisan ini ingin menggarisbawahi, bahwa muslim hub adalah darah nadi penghubung komunitas muslim dalam mekanisme jaringan,

\section{KESIMPULAN}

Komunitas muslim dunia adalah sebuah kekuatan pasar yang luar biasa yang tingkat pertumbuhan dan perkembangannya melampaui tingkat ratrata pertumbuha ekonomi dunia. Karena itu, komunitas muslim menjadi bagian yang sangat urgen dalam menciptakan tata dunia baru dalam lingkungan industry 4.0. 
Karakternya yang spesifik dan universal, memudahkan komunitas muslim untuk masuk menjadi bagian yang melekat dalam berbagai seksectoronomi, budaya, politik dan religiusitas.

Interaksi dan kontestasi ekonomi pasar mendorong lahirnya muslim hub sebagai urat nadi penghubung komunitas muslim dalam membentuk sinergi entitas bisnis yang kuat. Karenanya, komunitas muslim menjadi unsur yang kokoh yang tidak mudah diterpa gelombang kapitalisme Barat yang materialistic. Muslim hub menjadi bahasa yang tidak terucap untuk sebuah kepentingan muslim global, melalui mekanisme jaringan.

\section{REFERENSI}

C.K. Prahalad and V. Ramaswary, The Future of Competition: CoCreating Unique Value with Customer, Soundview Executive Book Sumaries, Pennsylvania 2004.

Dessy Kurnia Sari, Dick Mizerski and Fang Liu. (2017). Boycotting Foreign Product: A Study of Indonesian Muslim Consumers. Journal of Islamic Marketing, Vol. 8 No. 1.

John Naisbitt. (1995). Global Paradox: The Bigger the World Economy, the Powerful It's Smaller Players, Harper Collins.

John Naisbitt \& Patricia Aburdene. (1991). Megatrend 2000: New Directions Tomorrow, Harper Collins.

Khalil Al-Hyari, Muhammed Alnsour and Ghazi Al-Weshah. (2012). Religious Beliefs and Consumer Behaviour: From Loyalty to Boycotts, Journal of Islamic Marketing, Vol. 3 No. 2.
Muhammad Baehaqi. (2017). Customer Insight: Paradigma dan Konsep Strategi. Jurnal Fokus Bisnis, Volume 16. No. 2.

Pew Research Center's Forum on Religion \& Public Life. January 27, (2011). The Future of the Global Muslim Population Projections for 20102030,

Pink, Daniel H. (2005). A Whole New Mind: Why Right-Brainers Will Rule The World, Riverhead Books, New York.

Seth Godin. (2009). Segmentation is Communitization, Kompas.com.

Shelina Janmohamed. (2017) Generation M: Generasi Muda Muslim dan Cara Mereka Membentuk Dunia. Penerbit Bentang, Yogyakarta. Sulis Riptiono. (2017). Binding Customer Desires, Jurnal Fokus Bisnis. Vol. 16 No. 02.

Vargo, S. L., Maglio, P. P., \& Akaka, M. A. (2008). On Value and Value CoCreation: A Service Systems and Service Logic Perspective. European Management Journal, Vol. 26.

Vivek, S.D., Beatty, S.E., \& Morgan, R.M. (2012). Consumer Engagement: Exploring Customer Relationships Beyond Purchase. Journal of Marketing Theory and Practice, Vol. 20.

Wilson, Jonathan. AJ \& John Grant. (2013). Islamic Marketing: A Challenger to The Classical Marketing Canon?, Journal of Islamic Marketing, Vol. 4 No. 1.

Yuswohady. (2017). Generation Muslim, Islam Itu Keren. Penerbit Bentang, Yogyakarta,

Yuswohady. (2014). Marketing to The Middle Class Moslem, Gramedia Pustaka Utama, Jakarta. 